\title{
Prostaglandin G/H synthase-2 is required for maximal formation of osteoclast-like cells in culture
}

\author{
Yosuke Okada, ${ }^{1}$ Joseph A. Lorenzo, ${ }^{1}$ Amanda M. Freeman, ${ }^{1}$ Masato Tomita, ${ }^{1}$ \\ Scott G. Morham, ${ }^{2}$ Lawrence G. Raisz, ${ }^{1}$ and Carol C. Pilbeam ${ }^{1}$ \\ ${ }^{1}$ Department of Medicine, University of Connecticut Health Center, Farmington, Connecticut 06030, USA \\ ${ }^{2}$ Myriad Genetics Inc., Salt Lake City, Utah 84108, USA \\ Address correspondence to: Carol C. Pilbeam, University of Connecticut Health Center, 263 Farmington Avenue, Farmington, \\ Connecticut 06030, USA. Phone: (860) 679-2129; Fax: (860) 679-1258; E-mail: pilbeam@nso.uchc.edu.
}

This work was presented in part at the 21st annual meeting of the American Society for Bone and Mineral Research, St. Louis, Missouri, USA. October 3, 1999.

Received for publication August 10, 1999, and accepted in revised form January 27, 2000.

\begin{abstract}
We examined the effect on osteoclast formation of disrupting the prostaglandin $\mathrm{G} / \mathrm{H}$ synthase genes PGHS-1 and-2. Prostaglandin $\mathrm{E}_{2}\left(\mathrm{PGE}_{2}\right)$ production was significantly reduced in marrow cultures from mice lacking PGHS-2 (PGHS-2-/-) compared with wild-type $\left(\mathrm{PGHS}-2^{+/+}\right)$cultures. Osteoclast formation, whether stimulated by 1,25-dihydroxyvitamin $\mathrm{D}_{3}(1,25-\mathrm{D})$ or by parathyroid hormone (PTH), was reduced by $60-70 \%$ in PGHS-2 $2^{-/}$cultures relative to wild-type cultures, an effect that could be reversed by providing exogenous $\mathrm{PGE}_{2}$. Cultures from heterozygous mice showed an intermediate response. PGHS inhibitors caused a similar drop in osteoclast formation in wild-type cultures. Coculture experiments showed that supporting osteoblasts, rather than osteoclast precursors, accounted for the blunted response to 1,25-D and PTH. This lack of response appeared to result from reduced expression of RANK ligand (RANKL) in osteoblasts. We cultured spleen cells with exogenous RANKL and found that osteoclast formation was 50\% lower in PGHS-2-/- than in wild-type cultures, apparently because the former cells expressed high levels of GM-CSF. Injection of PTH above the calvaria caused hypercalcemia in wild-type but not $P G H S-2^{-/-}$mice. Histological examination of bone from 5week-old $P G H S-2^{-/}$mice revealed no abnormalities. Mice lacking PGHS-1 were similar to wild-type mice in all of these parameters. These data suggest that PGHS-2 is not necessary for wild-type bone development but plays a critical role in bone resorption stimulated by $1,25-\mathrm{D}$ and PTH.
\end{abstract}

J. Clin. Invest. 105:823-832 (2000).

\section{Introduction}

Prostaglandin $\mathrm{G} / \mathrm{H}$ synthase (PGHS), also called cyclooxygenase (COX), is the rate-limiting enzyme in the conversion of arachidonic acid released from membranes to prostanoids (1). The 2 enzymes for PGHS are encoded by separate genes and are differentially expressed. PGHS-1 (COX-1) is constitutively expressed; PGHS-2 (COX-2) is an inducible primaryresponse or immediate early gene (2). PGHS-1 and PGHS-2 may also differentially regulate prostaglandin production by using different substrates (3-5). Under conditions of limiting substrate, PGHS-2 appears to be the primary source of prostaglandin production (6). PGHS-2 is the enzyme that is largely responsible for prostaglandin responses in osteoblasts stimulated by multiple agonists (7).

Mice in which either the PGHS-1 or PGHS-2 gene is disrupted have been engineered (8-10). PGHS-1-deficient $\left(P G H S-1^{-/-}\right)$mice survive normally. PGHS-2-deficient $\left(\mathrm{PGHS}-2^{--}\right)$mice develop nephropathy that may limit life span. $P G H S-2^{-/-}$female mice have multiple defects in reproductive processes, including ovulation (absence of corpora lutea), fertilization, implantation, and decidualization, that are not caused by a deficien- cy of gonadotropins or ovarian hormones (11). The effect of a deficiency in PGHS-1 or PGHS- 2 on bone has not yet been examined in these mice.

Bone resorption is a highly regulated process involving interactions of osteoclastic precursors with osteoblasts or stromal cells (12-14). Prostaglandins are potent stimulators of resorption in organ culture (15). Many factors that stimulate prostaglandin production also stimulate resorption in organ culture (16-20). Stimulated osteoclast formation in marrow cultures is frequently found to be prostaglandin dependent $(18,21-31)$. We have examined the effects on osteoclast formation of disruption of $1\left(\mathrm{PGHS}^{-2^{+-}-}\right)$or both $\left(\mathrm{PGHS}-2^{---}\right)$PGHS-2 alleles using different in vitro systems to separate effects on osteoclast support cells and hematopoietic osteoclast precursors. We have also examined effects of disruption of PGHS-1 alleles (PGHS-1--).

\section{Methods}

Materials. $\mathrm{PGE}_{2}$ and indomethacin were purchased from Sigma (St. Louis, Missouri, USA). Parathyroid hormone (PTH; bovine 1-34) came from Bachem California (Torrance, California, USA) or Sigma. 1,25dihydroxyvitamin $\mathrm{D}_{3}(1,25-\mathrm{D})$ was purchased from 
Biomol Research Laboratories (Plymouth Meeting, Pennsylvania, USA). NS-398 came from Cayman Chemical Co. (Ann Arbor, Michigan, USA). FCS and $\alpha$-MEM were obtained from GIBCO BRL (McLean, Virginia, USA). Recombinant murine macrophageCSF (M-CSF), murine granulocyte-macrophage CSF (GM-CSF), and polyclonal GM-CSF antibody were obtained from R\&D Systems Inc. (Minneapolis, Minnesota, USA). $\mathrm{PGE}_{2}$ antibody for radioimmunoassay was purchased from Lawrence Levine (Brandeis University, Waltham, Massachusetts, USA). All other chemicals were obtained from Sigma. RANK ligand (RANKL) was kindly provided by Dirk Anderson (Immunex Corp., Seattle, Washington, USA).

Animals. PGHS-1 and PGHS-2 knockout mice were developed by homologous recombination in embryonic stem cells $(8,10)$. Because female $P G H S-1^{-/-}$and PGHS-2 $2^{-/-}$females have fertility and parturition problems, $P G H S-2^{-/-}$mice are produced by crossing heterozygous (+/-) mice. Because $P G H S-2^{+/-}$mice in a pure C57BL/ 6 background produce very few $P G H S-2^{-/-}$offspring, we mated +/- offspring of crosses between $\mathrm{C} 57 \mathrm{BL} / 6^{+/-}$and $\mathrm{C} 57 \mathrm{BL} / 6 \times 129 / \mathrm{sv}^{+/+}$to produce -/mice for PGHS-1 and PGHS-2 studies. Because of genetic variability, we analyzed individual littermates from multiple litters and performed multiple experiments to confirm reproducibility. Mice were genotyped and ears were notched for identification after weaning. Mice were sacrificed at 5-8 weeks of age. All animal protocols were approved by the Animal Care and Use Committees of the University of Connecticut Health Center.

For the PTH injections, 6-week-old C57BL/6 × 129
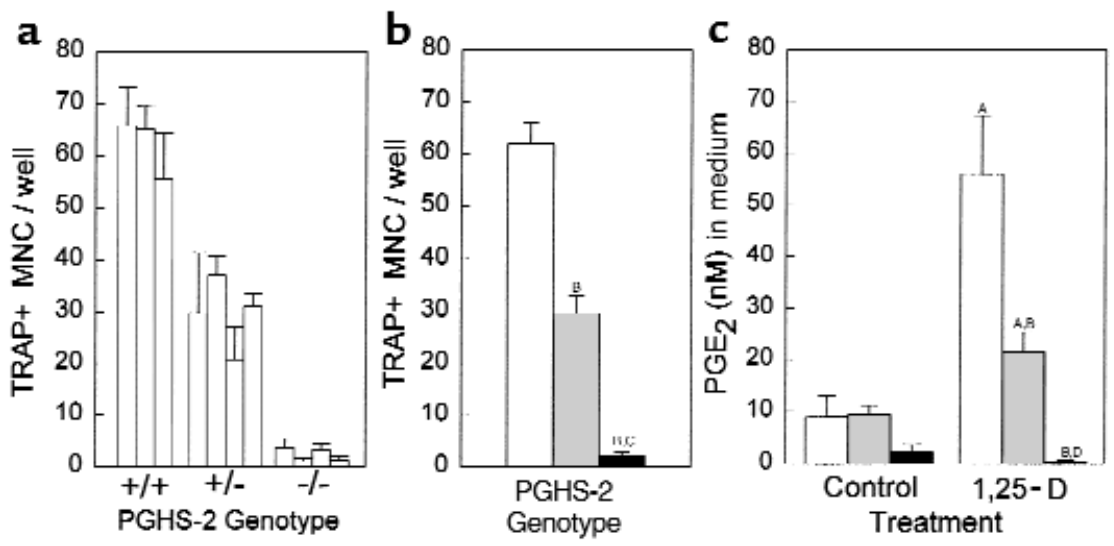

Figure 1

TRAP ${ }^{+} \mathrm{MNC}$ formation and $\mathrm{PGE}_{2}$ production in 1,25-D-stimulated bone marrow cultures from PGHS-2 ${ }^{+/+}, P G H S-2^{+/-}$, and $P G H S-2^{-/-}$mice. Cultures were treated for 8 days with vehicle (Control) or 1,25-D (10 nM). (a) Each bar represents the mean \pm SE of 3 replicate wells for marrow cultured from 1 mouse and treated with 1,25-D. All mice were from 2 litters born within a day of each other. No TRAP ${ }^{+} \mathrm{MNC}$ were seen in control cultures. (b) The mean ( $\pm \mathrm{SE}$ ) number of $\mathrm{TRAP}^{+} \mathrm{MNC}$ for each genotype was calculated from the mean for individual mice: $\mathrm{PGHS}-2^{+/+}$ (white bar), $\mathrm{PGHS}-2^{+/-}$(gray bar), and PGHS-2-/- (black bar). (c) Medium from 1 well per mouse was taken at the end of the culture period and assayed in duplicate for $\mathrm{PGE}_{2}$. Genotypes are as in $\mathbf{b}$. ASignificant difference from control group; $P<0.01$. ${ }^{\text {BSignificant difference from }}$ $P G H S-2^{+/+}$genotype; $P<0.01$. CSignificant difference from $P G H S-2^{+/-}$phenotype; $P<0.01$. DSignificant difference from ${ }^{+/-}$phenotype; $P<0.05$. mice were injected subcutaneously above the right hemicalvaria every 6 hours for 3 days with $0.025 \mathrm{~mL}$ of $10 \mu \mathrm{g}$ of PTH (Bachem California) or vehicle $(1 \mathrm{mM} \mathrm{HCl}$ with $\mathrm{mg} / \mathrm{mL}$ BSA). Venous blood was obtained by cavous sinus puncture. Serum creatinine concentrafrom Sigma. Total serum calcium and phosphate were measured in calorimetric assays using kits from Sigma. Genotyping of mice. Tail DNA was extracted following standard protocol, and was analyzed by PCR using primer sequences as described previously $(8,10)$. The the PCR conditions were 1 cycle of 2 minutes at $92^{\circ} \mathrm{C}$; , and 5 minutes at $65^{\circ} \mathrm{C}$. Products rate/EDTA buffer at $100 \mathrm{~V}$.

Primary osteoblastic cells. Calvariae were excised from 1-4 mice (5-7 weeks of age), dissected free of loose connective tissue, and washed with $\mathrm{PBS}$ at $\mathrm{pH}$ 7.4. Calvariere digested with $0.5 \mathrm{mg} / \mathrm{mL}$ of crude collagenase $\mathrm{mL}$ PBS for 10 minutes at $37^{\circ} \mathrm{C}$ with gentle rocking. The digestion procedure was repeated to provide 5 popations of cells (fraction 5 was digested for $20 \mathrm{~min}$ ). After each digestion, released cells were removed, and the reaction was stopped with $10 \%$ FCS. Cells from populations $2-5$ were pooled and then cultured to con-

fluence in $100-\mathrm{mm}$ dishes at $37^{\circ} \mathrm{C}$ in a humidified atmosphere of $5 \% \mathrm{CO}_{2}$, in phenol red-free DMEM with $10 \%$ heatinactivated FCS, $100 \mathrm{U} / \mathrm{mL}$ penicillin, and $50 \mu \mathrm{g} / \mathrm{mL}$ streptomycin. Cells were then resuspended and used in coculture experiments or replated in 6well dishes at 5,000 cells $/ \mathrm{cm}^{2}$.

Bone marrow cell cultures. Tibiae and femurs were aseptically dissected, the bone ends were cut off with scissors, and the marrow was flushed with $\alpha$-MEM. Collected marrow cells were washed with $\alpha$-MEM and then plated in $\alpha$-MEM containing $10 \%$ FCS at $10^{6}$ cells/well in 24-well plates (Corning-Costar Corp., Cambridge, Massachusetts, USA). Cells were cultured for 7 days at $37^{\circ} \mathrm{C}$ in a humidified atmosphere of $5 \% \mathrm{CO}_{2}$. On days 3 and $6,0.4 \mathrm{~mL}$ of the 0.5 $\mathrm{mL}$ of medium in each well was replaced with fresh medium. 


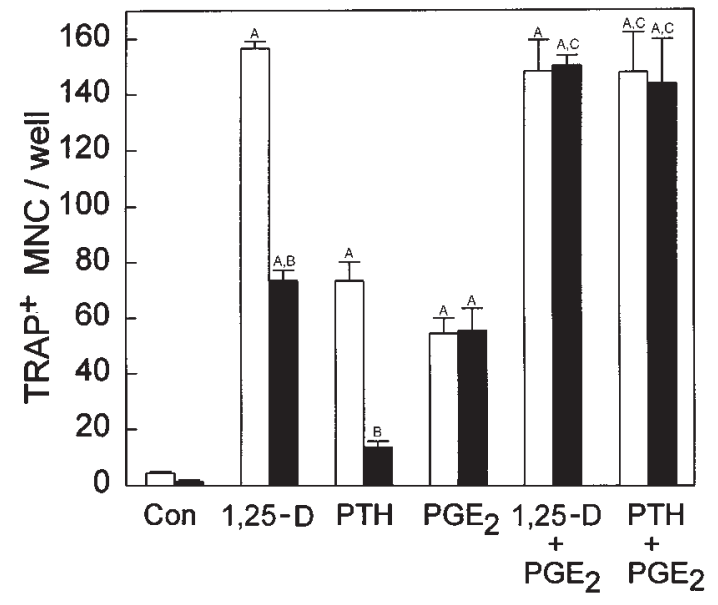

Figure 2

Effects of exogenous $\mathrm{PGE}_{2}$ on $\mathrm{TRAP}^{+} \mathrm{MNC}$ formation in bone marrow cultures treated with 1,25-D and PTH. Marrow was pooled from several $\mathrm{PGHS}-2^{+/+}$mice (white bars) or $\mathrm{PGHS}-2^{-/-}$mice (black bars) and was cultured for 7 days with vehicle (Con), 1,25-D (10 nM), or PTH $(10 \mathrm{nM})$, with and without $\mathrm{PGE}_{2}(1 \mu \mathrm{M})$. Bars represent mean $\pm \mathrm{SE}$ for $\mathrm{TRAP}^{+} \mathrm{MNC}$ formation in 6 wells. ${ }^{A}$ Significant difference from control group; $P<0.01$. BSignificant difference from comparably treated $+/+$ genotype; $P<0.01$. 'Significant effect of addition of $\mathrm{PGE}_{2} ; P<0.01$.

Cultures were treated with 1,25-D (10 nM), PTH (10 $\mathrm{nM})$, or $\mathrm{PGE}_{2}(1 \mu \mathrm{M})$, added at the beginning of the culture and at each medium change. Osteoclast-like cell (OCL) formation was measured by $\mathrm{TRAP}^{+}$multinucleated cell formation. At the end of the culture period, cells were washed with PBS and fixed with $2.5 \%$ glutaraldehyde for 30 minutes. Cells were stained for TRAP using a leukocyte acid phosphatase A kit (Sigma). The number of $\mathrm{TRAP}^{+} \mathrm{MNC}$ per well was counted under a microscope.

Cocultures. Spleen cells were prepared by macerating spleen tissues with a needle. The spleen cells $\left(10^{6}\right.$ cells/well) were cocultured with primary calvarial osteoblasts $\left(10^{4}\right.$ cells/well) in $0.5 \mathrm{~mL} \alpha$-MEM supplemented with $10 \%$ FCS in 24-well plates. Cultures were treated with $1,25-\mathrm{D}, \mathrm{PTH}$, or $\mathrm{PGE}_{2}$, and were maintained for 7 days following the same protocol described for bone marrow cultures, except that the media was completely changed at day 3 . At the end of the culture period, the cells were stained for TRAP, and $\mathrm{TRAP}^{+}$ MNC per well were counted.

Spleen cell cultures. Spleen cells were prepared and cultured as described above for 6 days in the presence of RANKL (10 ng/mL) and M-CSF (10 ng/mL).

Pit formation assay. Marrow cells, cultured as described above for 7 days with 1,25-D or PGE 2 , were resuspended and allowed to settle onto the surface of devitalized bovine cortical bone slices $(4.4 \times 4.4 \times 0.2 \mathrm{~mm})$ for 90 minutes in PBS. Bone slices were rinsed vigorously and incubated for 24 hours at $37^{\circ} \mathrm{C}$ in $\alpha$-MEM (with 0.7 $\mathrm{g} / \mathrm{L}$ of sodium bicarbonate) and $10 \%$ FCS. After incubation, samples were fixed with $2.5 \%$ glutaraldehyde in PBS for 30 minutes, cells were stained for TRAP, and bone slices were stained with $1 \%$ toluidine blue in $1 \%$ borax. The number of resorption pits per bone slice was counted using reflective light microscopy.

$R T-P C R$. Total RNA was extracted according to the method of Chomczynski and Sacchi as described previously (32). Total RNA was converted to cDNA by reverse transcriptase (Superscript II; GIBCO BRL) and random hexamer. PCR amplification was done using Taq polymerase (AmpliTaq; Perkin-Elmer Corp., Norwalk, Connecticut, USA) in a thermal cycler (PerkinElmer Corp.). After a hot start, temperature cycling was as follows: denaturation at $94^{\circ} \mathrm{C}$ for 1 minute, primer annealing at $65^{\circ} \mathrm{C}$ for 1 minute, and extension at $72^{\circ} \mathrm{C}$ for 2 minutes for 10 cycles. In subsequent cycles, the primer annealing temperature was decreased stepwise by $5^{\circ} \mathrm{C}$ every 5 cycles. After the last cycle, the mixture was incubated at $72^{\circ} \mathrm{C}$ for 7 minutes. To verify that amplification was in the linear range, we performed PCR amplification for 27-35 cycles.

PCR primers for murine GAPDH and GM-CSF were purchased from CLONTECH Laboratories Inc. (Palo Alto, California, USA). Primers for murine
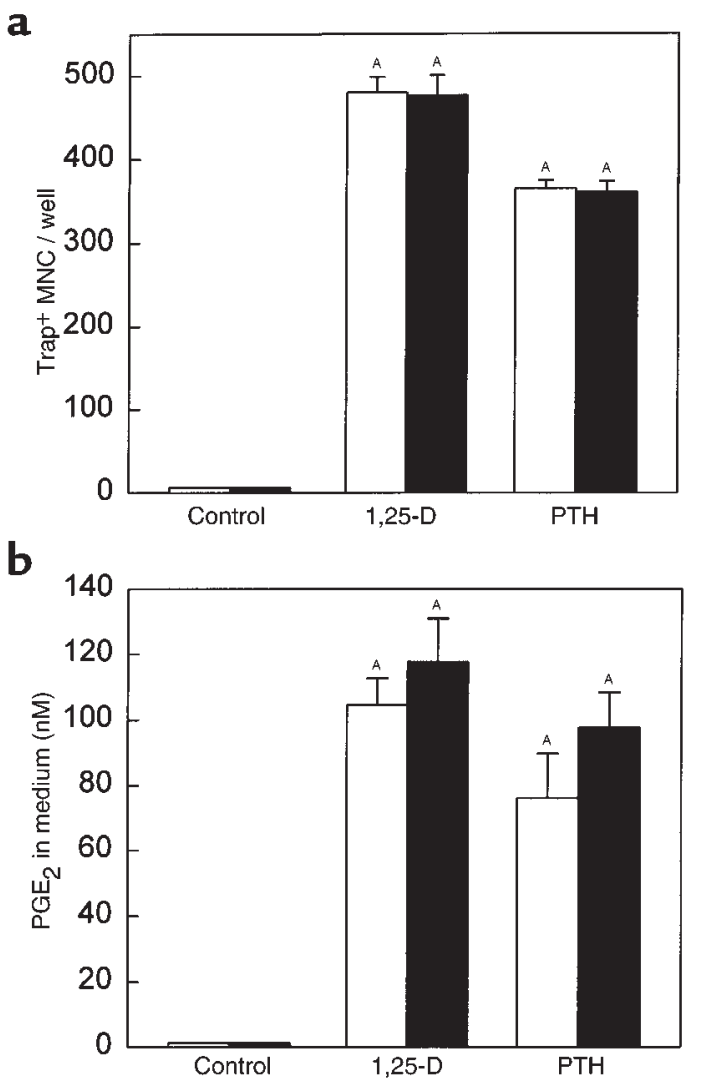

Figure 3

Effect of PGHS-1 gene disruption on TRAP ${ }^{+}$MNC formation and $\mathrm{PGE}_{2}$ production in marrow culture. Marrow from $\mathrm{PGHS}-1$ knockout mice (black bars) or from wild-type littermates (white bars) was cultured with vehicle (Control) or 1,25-D (10 nM) for 7 days. (a) Bars represent mean $\pm \mathrm{SE}$ for $\mathrm{TRAP}^{+} \mathrm{MNC}$ in 4 wells. (b) Bars represent mean $\pm \mathrm{SE}$ for medium $\mathrm{PGE}_{2}$ produced during the last 2 days of culture in 4 wells. ${ }^{A}$ Significant difference from control group; $P<0.01$. 


\section{a}

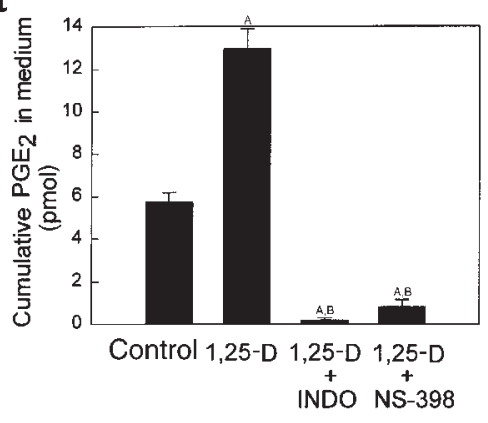

b

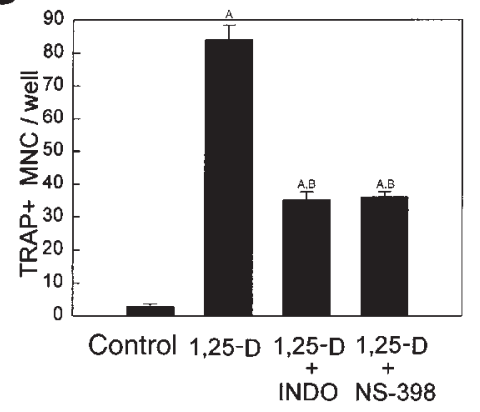

C

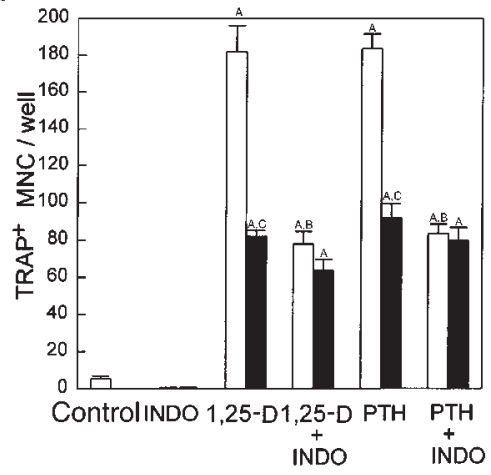

Figure 4

Effect of inhibitors of PGHS-1 and PGHS-2 activity on TRAP ${ }^{+}$MNC formation in bone marrow cultures. Marrow was cultured for 7 days with vehicle (Con), 1,25-D (10 nM), or PTH (10 nM) in the presence or absence of either $0.1 \mu \mathrm{M}$ indomethacin (INDO; an inhibitor of both PGHS-1 and PGHS-2 activity) or $0.1 \mu$ M NS-398, a selective inhibitor of PGHS-2 activity. Bars represent mean \pm SE of 4 wells. Comparison of 1,25-D-stimulat-

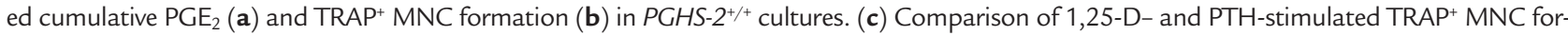
mation, with and without indomethacin, in $P G H S-2^{+/+}$cultures (white bars) and $P G H S-2^{-/-}$cultures (black bars). ${ }^{A}$ Significant difference from control group; $P<0.01$. BSignificant effect of inhibitor; $P<0.01$. CSignificant difference from $+/+$ genotype; $P<0.01$.

RANKL (5'-GGGAATTACAAAGTGCACCAG-3' and 5'GGTCGGGCAATTCTGAATT-3) were designed from published DNA sequences (33). Amplified products were run on a $1 \%$ agarose gel, stained with ethidium bromide, and photographed under UV illumination. Images were analyzed with either ScanAnalysis 2.56 (Biosoft, Cambridge, United Kingdom) or NIH Image 1.61.

$P G E_{2}$ assay. Medium was removed from cultured cells and $\mathrm{PGE}_{2}$ levels were measured by radioimmunoassay as described previously (34).

Statistical analysis. Significant differences among groups within each experiment were determined by ANOVA, followed by post-hoc testing using Bonferroni's method. When data from multiple experiments were pooled, statistical differences between wild-type and knockout genotypes were determined by Student's $t$ test.

\section{Results}

Phenotype of PGHS-2+/- and PGHS-2-/- mice. Mice used for in vitro assays were 5-7 weeks of age and appeared healthy and active. There were no significant differences in body weight or serum creatinine between groups (Table 1). Preliminary data on the histology and histomorphometry of $3 \mathrm{PGHS}-2^{+/+}$and $3 \mathrm{PGHS}-2^{-/-}$mice at 5

Table 1

Comparison of body weights and serum creatinine levels in PGHS$2^{+/+}, \mathrm{PGHS}-2^{+/-}$, and $\mathrm{PGHS}-2^{-/-}$mice

\begin{tabular}{lcc}
\hline Genotype & Body weight & Serum creatinine \\
& $(\mathrm{g})$ & $(\mathrm{mg} / \mathrm{dL})$ \\
$P G H S-2^{+/+}$ & $16.7 \pm 1.7$ & $0.93 \pm 0.02$ \\
$P G H S-2^{+-}$ & $16.6 \pm 0.9$ & $0.93 \pm 0.01$ \\
$P G H S-2^{-/-}$ & $15.1 \pm 1.9$ & $0.96 \pm 0.04$
\end{tabular}

Data are mean \pm SE for 5 -week-old C57BL/6 $\times 129$ mice. Each group includes 2 males and 2 females from 2 litters. weeks of age showed no differences in the proximal tibia (data not shown).

Stimulated $O C L$ formation and $P G E_{2}$ production in marrow cultures. In our initial experiments, we cultured marrow individually from all mice in 2 litters born within a day of each other (Figure 1a). Marrow for each mouse was cultured in 3 replicate wells, and the average number of $\mathrm{TRAP}^{+} \mathrm{MNC}$ per well for each mouse was then used to calculate the mean for each treatment group (Figure $1 \mathrm{~b}$ ). There was a $50 \%$ reduction in 1,25 -D-stimulated (10 $\mathrm{nM}) \mathrm{TRAP}^{+} \mathrm{MNC}$ formation in $\mathrm{PGHS}-2^{+/-}$cultures, and a 96\% reduction in $P G H S-2^{-/-}$cultures compared with PGHS- $2^{+/+}$cultures. Treatment with 1,25-D increased $\mathrm{PGE}_{2}$ in the medium 6-fold in $\mathrm{PGHS}-2^{+/+}$cultures (Figure 1c). The 1,25-D-stimulated increase in $\mathrm{PGE}_{2}$ was $62 \%$ lower in $\mathrm{PGHS}-2^{+/-}$cultures and 99\% lower in $\mathrm{PGHS}-2^{-/-}$ cultures than in the $\mathrm{PGHS}-2^{+/+}$cultures. In subsequent experiments, marrow cultures pooled from several mice of the same genotype were compared.

Induction of $\mathrm{TRAP}^{+} \mathrm{MNC}$ formation by PTH $(10 \mathrm{nM})$ was similarly reduced in $P G H S-2^{-/-}$marrow cultures compared with $\mathrm{PGHS}-2^{+/+}$cultures (Figure 2 ). In this same experiment, 1,25-D and PTH stimulated 3-fold and 2.5-fold increases, respectively, in $\mathrm{PGE}_{2}$ levels in the medium of $P G H S-2^{+/+}$cultures $(P<0.01)$, but did not increase levels in $\mathrm{PGHS}-2^{-/-}$cultures (data not shown).

In 6 separate experiments, the mean reduction $( \pm S E)$ in 1,25 -D-stimulated $\mathrm{TRAP}^{+} \mathrm{MNC}$ formation per well in PGHS-2 ${ }^{-/-}$cultures relative to $\mathrm{PGHS}-2^{+/+}$cultures was $72 \pm$ $9 \%(P<0.01)$. In 3 separate experiments, the mean reduction in 1,25-D-stimulated TRAP $\mathrm{MNC}^{+}$in $\mathrm{PGHS}-2^{+/-}$cultures relative to $P G H S-2^{+/+}$cultures was $51 \pm 1 \%(P<0.01)$. In 5 separate experiments, the mean reduction in PTHstimulated TRAP ${ }^{+} \mathrm{MNC}$ formation in $\mathrm{PGHS}^{-2^{-/}}$cultures relative to $P G H S-2^{+/+}$cultures was $64 \pm 5 \%(P<0.01)$.

Treatment with $\mathrm{PGE}_{2}(1 \mu \mathrm{M})$ stimulated $\mathrm{TRAP}^{+}$ MNC formation in $\mathrm{PGHS}-2^{+/+}$marrow cultures; this stimulation was not reduced in $\mathrm{PGHS}-2^{-/-}$cultures (Fig- 
Table 2

Effects of local PTH injection above the calvaria of $\mathrm{PGHS}^{-2^{+/+}}$and PGHS-2 ${ }^{-/-}$mice

\begin{tabular}{lcccc}
\hline \multirow{2}{*}{ Measurement } & \multicolumn{2}{c}{ Vehicle injected } & \multicolumn{2}{c}{ PTH injected } \\
& ${\mathrm{PGHS}-2^{+/+}}^{\text {PGHS-2-/- }}$ & PGHS-2 ${ }^{+/+}$ & PGHS-2-/- \\
$\begin{array}{l}\text { Body weight } \\
\text { (g) }\end{array}$ & $16.9 \pm 0.1$ & $18.2 \pm 1.8$ & $15.8 \pm 0.5$ & $15.3 \pm 0.9$ \\
$\begin{array}{l}\text { Serum creatinine } \\
\text { (mg/dL) }\end{array}$ & $0.98 \pm 0.09$ & $0.96 \pm 0.16$ & $0.88 \pm 0.09$ & $1.05 \pm 0.13$ \\
$\begin{array}{l}\text { Serum calcium } \\
\text { (mg/dL) }\end{array}$ & $8.7 \pm 0.1$ & $9.1 \pm 0.2$ & $12.0 \pm 0.3^{\mathrm{A}}$ & $9.0 \pm 0.5$ \\
$\begin{array}{l}\text { Serum phosphate } \\
(\mathrm{mg} / \mathrm{dL})\end{array}$ & $7.2 \pm 0.5$ & $7.4 \pm 0.5$ & $6.6 \pm 0.6$ & $8.3 \pm 0.5$ \\
\hline
\end{tabular}

Data are mean \pm SE for 6 -week-old mice $(n=3)$. There were 2 males and 1 female in the vehicle-treated groups, and 1 male and 2 females in the PTHtreated groups. ASignificantly different from vehicle-treated groups and from PTH-treated $P$ GHS- $2^{-1-}$ mice; $P<0.01$.

ure 2). There was no reduction in $\mathrm{PGE}_{2}$-stimulated $\mathrm{TRAP}^{+} \mathrm{MNC}$ formation in $\mathrm{PGHS}-2^{+/-}$or $\mathrm{PGHS}^{-/-}$cultures in 4 additional experiments. $\mathrm{PGE}_{2}(1 \mu \mathrm{M})$ added to 1,25 -D-stimulated cultures reversed the reduction in $\mathrm{TRAP}^{+} \mathrm{MNC}$ formation in PGHS-2-/- cultures (Figure 2). Addition of $\mathrm{PGE}_{2}$ to PTH-stimulated $\mathrm{PGHS}-2^{-1-}$ cultures enhanced $\mathrm{TRAP}^{+} \mathrm{MNC}$ formation in PGHS$2^{+/+}$cultures and eliminated differences between the wild-type and PGH-2-deficient cultures.

Effect of PGHS-1 deficiency on stimulated OCL formation in marrow cultures. There was no reduction in 1,25-Dor PTH-stimulated $\mathrm{TRAP}^{+} \mathrm{MNC}$ formation in marrow cultures from $\mathrm{PGHS}-1^{-/-}$mice compared with $\mathrm{PGHS}-1^{+/+}$ cultures (Figure $3 \mathrm{a}$ ). In addition, there was no reduction in 1,25-D- or PTH-stimulated $\mathrm{PGE}_{2}$ production in PGHS-1 ${ }^{-/-}$cultures (Figure $3 \mathrm{~b}$ ).

Effects of nonsteroidal anti-inflammatory drugs (NSAIDs) on stimulated OCL formation in marrow cultures. To assess further the relative roles of PGHS- 2 and PGHS- 1 in stimulated OCL formation in marrow cultures, we compared PGHS-2+/+ marrow cultures treated with $0.1 \mu \mathrm{M}$ indomethacin, which inhibits both PGHS-1 and PGHS2 activity, and cultures treated with NS-398 (0.1 $\mu \mathrm{M})$, a selective inhibitor of PGHS-2 in osteoblastic cells (35). Both NSAIDs inhibited $\mathrm{PGE}_{2}$ production in 1,25 D-stimulated marrow cultures (Figure 4a) and decreased $\mathrm{TRAP}^{+} \mathrm{MNC}$ formation by $60-65 \%$ (Figure $4 \mathrm{~b}$ ). We also examined the effects of indomethacin on 1,25-D- or PTH-stimulated PGHS-2 ${ }^{+/+}$and $P G H S-2^{-/-}$marrow cultures to determine if the residual stimulated OCL formation in PGHS-2-/- cultures could be reduced by inhibiting PGHS-1 activity (Figure 4c). Treatment with indomethacin caused no additional reduction in OCL formation in $\mathrm{PGHS}-2^{-/-}$cultures (Figure 4c).

Effects of PGHS-2 deficiency on pit formation. We assessed the ability of OCL formed in marrow cultures to form resorption pits on cortical bone slices (Figure 5). 1,25D stimulated an 8-fold increase in the number of pits formed by marrow cells from $\mathrm{PGHS}-2^{+/+}$mice. 1,25D-stimulated pit formation was reduced by $60 \%$ in marrow cultured from $P G H S-2^{-/-}$mice; this reduction was reversed by treatment with $\mathrm{PGE}_{2}$. There was no difference in pit area among groups (data not shown).

Stimulated OCL formation in cocultures of spleen and osteoblastic cells. We cocultured $\mathrm{PGHS}-2^{+/+}$and $\mathrm{PGHS}-2^{-/-}$ spleen cells (as a source of osteoclastic precursors) with primary osteoblasts derived from calvariae of $\mathrm{PGHS}-2^{+/+}$ and PGHS-2-/- mice. 1,25-D- and PTH-stimulated (Figures $6 \mathrm{a}$ and $6 \mathrm{~b}$, respectively) $\mathrm{TRAP}^{+} \mathrm{MNC}$ formation was reduced $65 \%$ and $80 \%$, respectively, in cocultures of PGHS-2 $2^{-/-}$osteoblasts with either $\mathrm{PGHS}-2^{+/+}$or $\mathrm{PGHS}$ $2^{-/-}$spleen cells. Stimulated OCL formation was not inhibited when $\mathrm{PGHS}-2^{-/-}$spleen cells were cultured with $\mathrm{PGHS}-2^{+/+}$osteoblasts. Addition of $\mathrm{PGE}_{2}$ reversed the inhibition of $\mathrm{TRAP}^{+} \mathrm{MNC}$ formation in cocultures with $P G H S-2^{-/-}$osteoblasts. The effect of $\mathrm{PGE}_{2}$ on $\mathrm{TRAP}^{+} \mathrm{MNC}$ formation was additive to the effect of PTH in cocultures with $\mathrm{PGHS}-2^{+/+}$osteoblasts. Similar results were seen in 2 more experiments with PTH, and in a second experiment with 1,25-D.

\section{Figure 5}

Formation of resorption pits on cortical bone slices by cultured marrow cells from $\mathrm{PGHS}-2^{+/+}$mice (white bars) and $P G H S-2^{-/-}$mice (black bars). Cultures were treated with either vehicle (Control) or 1,25-D $(10 \mathrm{nM})$ with and without $\mathrm{PGE}_{2}(1$ $\mu \mathrm{M})$. An osteoclast resorption pit was defined as having multiple overlapping resorption lacunae. (a) Photomicrograph of resorption pits on cortical bone. (b) Number of resorption pits counted on 6 bone slices (mean $\pm \mathrm{SE}$ ). ${ }^{\text {ASignificant dif- }}$ ference from control group; $P<$ 0.01 . BSignificant difference from 1,25-D-treated $P G H S-2^{+/+}$cells; $P<$ 0.05 . 'Significant effect of addition of $\mathrm{PGE}_{2} ; P<0.01$. a

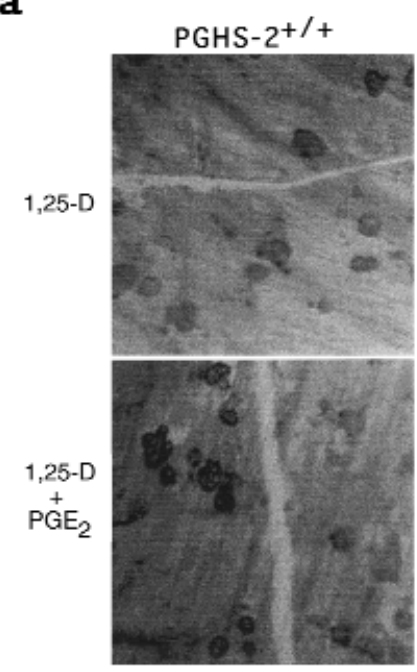

b

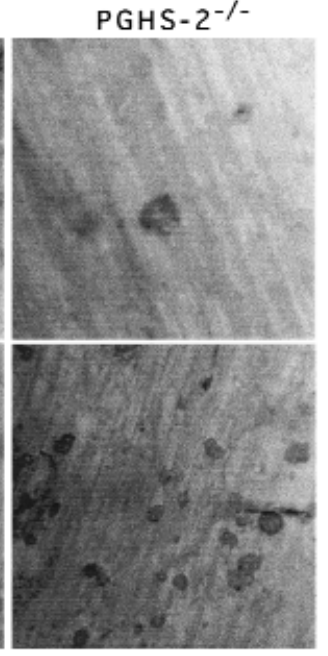

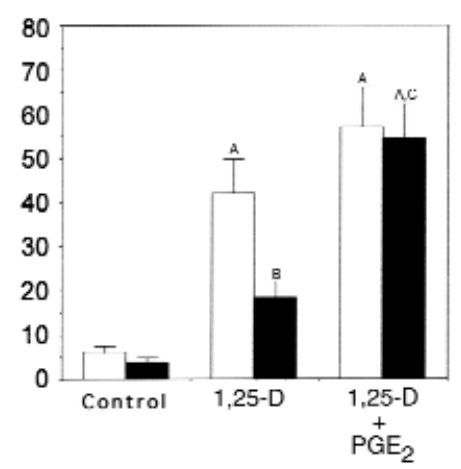


Injection of PTH over the calvaria. To determine if there were in vivo consequences of the differences in OCL formation seen in vitro, we examined the ability of PTH injected subcutaneously above the calvaria to raise serum calcium levels in $\mathrm{PGHS}-2^{+/+}$and $\mathrm{PGHS}-2^{-/-}$mice. Following an established model $(36,37), 6$-week-old mice ( 3 in each group) were injected 4 times a day for 3 days above the right hemicalvaria with $10 \mu \mathrm{g}$ of PTH or vehicle. Serum was obtained 2 hours after the last injection. There was no significant difference in body weight, serum creatinine, or serum phosphate among the groups (Table 2). There was no difference between serum calcium levels in $\mathrm{PGHS}-2^{+/+}$and $\mathrm{PGHS}-2^{-/-}$mice injected with vehicle. PTH injection produced marked hypercalcemia in the $\mathrm{PGHS}-2^{+/+}$mice but did not elevate
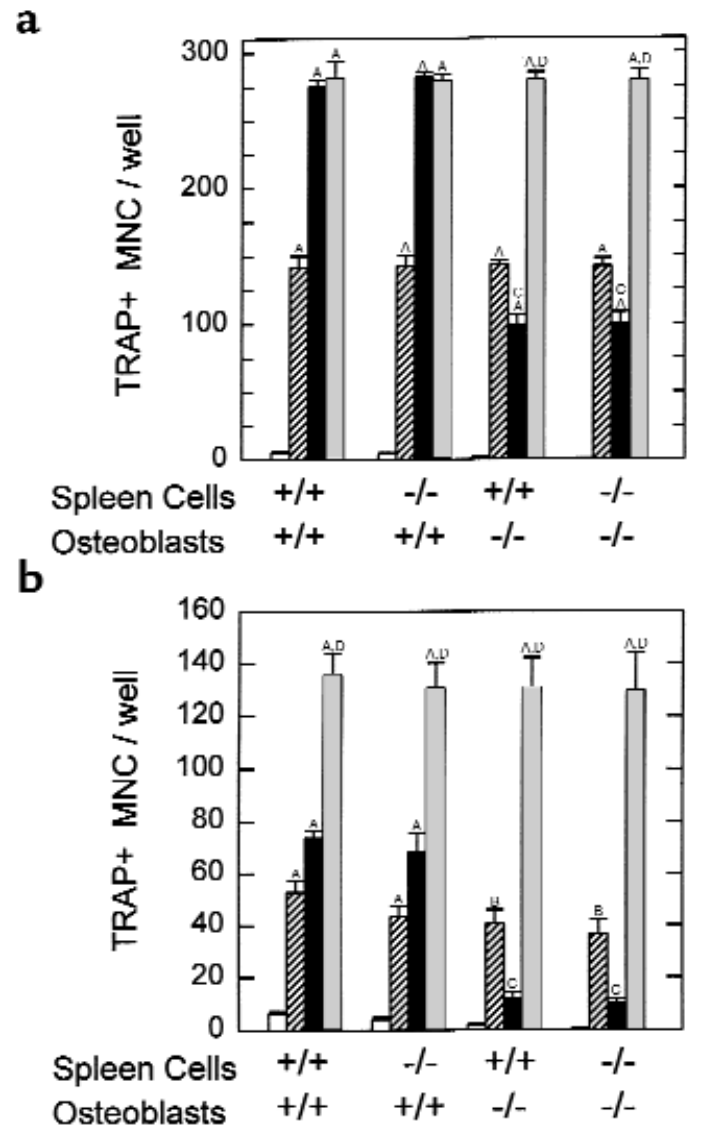

\section{Figure 6}

$\mathrm{TRAP}^{+} \mathrm{MNC}$ formation in cocultures of spleen cells and primary osteoblasts from $\mathrm{PGHS}_{-} 2^{+/+}$and $\mathrm{PGHS}-2^{-/-}$mice. Osteoblasts were pooled from 4 populations from sequentially digested calvariae. Cocultures were treated with 1,25-D (10 nM) or PTH (10 nM), with or without $\mathrm{PGE}_{2}(1 \mu \mathrm{M})$ for 7 days and then stained for TRAP. Bars represent mean \pm SE of quadruplicate cultures. (a) Cultures were treated with vehicle (open bars), $\mathrm{PGE}_{2}$ (striped bars), 1,25-D (black bars), or 1,25-D + $\mathrm{PGE}_{2}$ (gray bars). (b) Cultures were treated with vehicle (open bars), $\mathrm{PGE}_{2}$ (striped bars), PTH (black bars), or PTH $+\mathrm{PGE}_{2}$ (gray bars). ${ }^{\mathrm{A} S i g n i f i c a n t ~ d i f f e r e n c e ~ f r o m ~ v e h i c l e ~ t r e a t m e n t ; ~} P$ $<0.01$. BSignificant difference from vehicle treatment; $P<0.05$. 'Significant effect of $P G H S-2^{-1-}$ osteoblasts; $P<0.01$. DSignificant difference from treatment with either agent alone; $P<0.01$. serum calcium in the PGHS-2-/- mice (Table 2).

Regulation of RANKL $m R N A$ expression in osteoblasts. Because stimulation of RANKL expression in osteoblasts has been shown to be essential for resorption induced by $1,25-\mathrm{D}, \mathrm{PTH}$, and $\mathrm{PGE}_{2}$ (38-41), we examined the stimulation of RANKL expression in $\mathrm{PGHS}_{-2^{+/+}}$and $\mathrm{PGHS}-2^{-/-}$cultures. We measured RANKL mRNA levels in 3 separate experiments by RTPCR in primary calvarial osteoblast cultures grown to confluence and treated for 24 hours with 1,25-D and PTH. 1,25-D-stimulated RANKL mRNA levels were reduced $47 \pm 2 \%(P<0.01)$ in $P G H S-2^{-/-}$cultures compared with $\mathrm{PGHS}-2^{+/+}$cultures (data not shown). PTHstimulated RANKL mRNA levels were reduced $56 \pm 8 \%$ $(P<0.01)$ in $P G H S-2^{-/}$cultures compared with $P G H S$ $2^{+/+}$cultures (data not shown).

OCL formation in RANKL and M-CSF-treated spleen cell cultures. To examine the effects of PGHS-2 deficiency on differentiation of osteoclast precursors without using osteoblastic cells, we used spleen cell cultures treated with RANKL (10 ng/mL) and M-CSF $(10 \mathrm{ng} / \mathrm{mL})$ (42, 43). We were unable to detect mRNA for RANKL by RT-PCR in these spleen cell cultures, indicating that few stromal or osteoblastic cells were present (data not shown). There were 2- to 3-fold more $\mathrm{TRAP}^{+} \mathrm{MNCs}$ in PGHS-2 ${ }^{+/+}$cultures than in PGHS-2-/- cultures (Figures 7 and 9). In contrast, we found no difference in OCL formation in spleen cell cultures from $\mathrm{PGHS}-1^{-/-}$mice compared with $\mathrm{PGHS}-1^{+/+}$cultures (data not shown).

In multiple experiments, we found no $\mathrm{TRAP}^{+} \mathrm{MNC}$ formed in the absence of RANKL and M-CSF. As reported previously (44), addition of $\mathrm{PGE}_{2}(1 \mu \mathrm{M})$ to cultures treated with RANKL and M-CSF increased $\mathrm{TRAP}^{+} \mathrm{MNC}$ formation (Figures 7 and 8 ). In the experiment shown in Figure 7, treatment of $\mathrm{PGHS}-2^{-/-}$spleen cells with $\mathrm{PGE}_{2}$ did not completely reverse the deficit in $\mathrm{TRAP}^{+} \mathrm{MNC}$ formation that was observed in $\mathrm{PGHS}-2^{-/-}$ cultures compared with $\mathrm{PGE}_{2}$-treated $\mathrm{PGHS}-2^{+/+}$cultures. In 2 similar experiments, however, there was a complete reversal of this deficit (Figure 9). $\mathrm{PGE}_{2}$ did not stimulate $\mathrm{TRAP}^{+} \mathrm{MNC}$ formation in cultures without RANKL and M-CSF (data not shown). As seen previously (44), addition of $\mathrm{PGE}_{2}$ to spleen cell cultures decreased the total number of cells present at the end of the culture period (Figure 8).

$\mathrm{PGE}_{2}$ levels in medium were barely detectable by our radioimmunoassay for $\mathrm{PGE}_{2}$ (lower limit $0.1 \mathrm{nM}$ ) in both $\mathrm{PGHS}-2^{+/+}$and $\mathrm{PGHS}-2^{-/-}$spleen cell cultures (data not shown). This observation is consistent with the absence of osteoblasts and other stromal cells in these cultures. Treatment with indomethacin $(0.1 \mu \mathrm{M})$ to block prostaglandin production throughout the culture period did not inhibit OCL formation (data not shown).

Regulation of GM-CSF in RANKL- and M-CSF-treated spleen cell cultures. Because GM-CSF has been shown to inhibit murine osteoclastogenesis $(45,46)$, we measured GM-CSF mRNA levels by RT-PCR in the spleen cell cultures. In the experiment shown in Figure 7, the GM-CSF mRNA level was increased 3.5-fold in PGHS- 
a

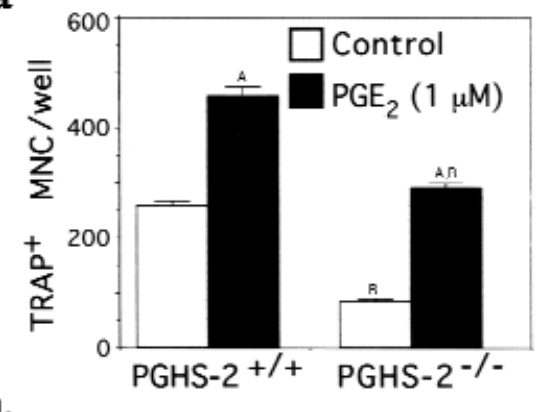

b
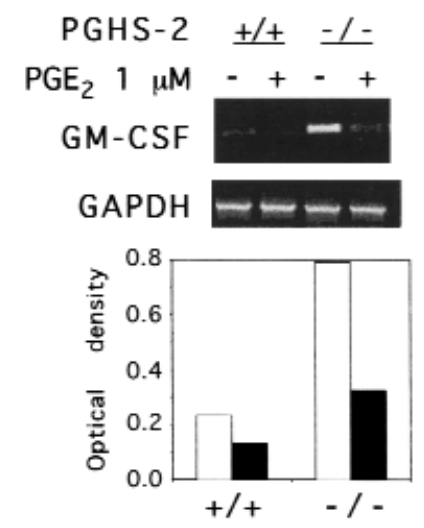

PGHS-2

\section{Figure 7}

Effect of disruption of the PGHS-2 gene on TRAP ${ }^{+}$MNC formation and GM-CSF mRNA expression in spleen cells cultured without osteoblasts. Cultures were treated with M-CSF $(10 \mathrm{ng} / \mathrm{mL})$ and RANKL $(10$ $\mathrm{ng} / \mathrm{mL}$ ), and then with either vehicle (Control; white bars) or PGE 2 (1 $\mu \mathrm{M}$; black bars). (a) TRAP ${ }^{+}$MNC formed after 6 days of culture. Data are expressed as mean \pm SE for quadruplicate cultures. (No TRAP ${ }^{+}$ MNC were formed in cultures without RANKL and M-CSF; data not

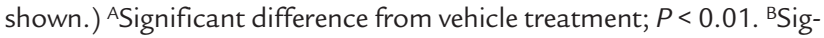
nificant effect of $P G H S-2^{-1-}$ genotype; $P<0.01$. (b) RT-PCR analysis of GM-CSF mRNA levels at the end of the culture period for the experiment shown in a. Ethidium bromide-stained RT-PCR products are shown in the top panel. The optical density ratios of GM-CSF mRNA to GAPDH mRNA are shown in the bottom panel.

$2^{-/-}$spleen cells compared with $P G H S-2^{+/+}$cells, and the number of TRAP ${ }^{+}$MNC was 3.2-fold higher in PGHS$2^{+/+}$cultures than in PGHS-2-/- cultures. In a second and similar experiment, there was a 2 -fold increase in GMCSF mRNA levels in PGHS-2-/- spleen cell cultures compared with $\mathrm{PGHS}-2^{+/+}$cultures, and the number of $\mathrm{TRAP}^{+} \mathrm{MNC}$ was 2 -fold higher in $\mathrm{PGHS}-2^{+/+}$cultures than in PGHS-2-/- cultures (data not shown). Addition of $\mathrm{PGE}_{2}(1 \mu \mathrm{M})$ decreased GM-CSF mRNA levels in both $\mathrm{PGHS}-2^{+/+}$and $\mathrm{PGHS}-2^{-/-}$cultures (Figure 7).

If the decrease in $\mathrm{TRAP}^{+} \mathrm{MNC}$ formation in PGHS$2^{-/-}$spleen cell cultures relative to $\mathrm{PGHS}-2^{+/+}$cultures is due to increased GM-CSF production, then a blocking antibody to GM-CSF should increase TRAP ${ }^{+}$MNC formation in $P G H S-2^{-/-}$spleen cell cultures and eliminate differences between $\mathrm{PGHS}-2^{-{ }^{-}}$and $\mathrm{PGHS}-2^{+/+}$cultures. Murine GM-CSF $(1 \mathrm{ng} / \mathrm{mL})$ inhibited $\mathrm{TRAP}^{+} \mathrm{MNC}$ formation by $90 \%$ in RANKL- and M-CSF-stimulated

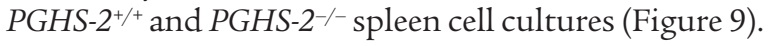

Polyclonal antibody to murine GM-CSF at a concentration of $0.1 \mu \mathrm{g} / \mathrm{mL}$ blocked the GM-CSF inhibition of $\mathrm{TRAP}^{+} \mathrm{MNC}$ formation in spleen cell culture, and at higher doses $(1.0-10 \mu \mathrm{g} / \mathrm{mL})$ the antibody increased $\mathrm{TRAP}^{+} \mathrm{MNC}$ formation 2-fold, with maximal effects at $1 \mu \mathrm{g} / \mathrm{mL}$ (data not shown). Addition of $1.0 \mu \mathrm{g} / \mathrm{mL}$ anti-GM-CSF antibody to $\mathrm{PGHS}-2^{+/+}$and $\mathrm{PGHS}-2^{-/-}$ spleen cell cultures reversed the inhibitory effects of GM-CSF and enhanced OCL formation to similar levels in both PGHS-2+/+ and PGHS-2-/- cultures (Figure 9). $\mathrm{PGE}_{2}$ alone enhanced OCL formation to a level similar to that induced by the antibody in both $\mathrm{PGHS}-2^{+/+}$and PGHS-2-/- cultures. $\mathrm{PGE}_{2}$ did not add further to the antibody effect, and could not overcome the inhibitory effect of added GM-CSF.

\section{Discussion}

Prostaglandins of the E series are potent stimulators of bone resorption in organ culture, and $\mathrm{PGE}_{1}$ and $\mathrm{PGE}_{2}$ (but not $\mathrm{PGF}_{2 \alpha}$ ) stimulate osteoclast formation in marrow cultures $(47,48)$. Agonists reported to stimulate prostaglandin-dependent OCL formation include IL-1 (18, 22, 23), TNF- $\alpha(23)$, PTH $(24,25)$, 1,25-D (26), IL-11 (27, 28), IL-6 (21), IL-17 (31), phorbol ester (29), and FGF-2 (30). Our results support the conclusion of these earlier studies that prostaglandins play an important role in the response of bone-to-bone resorbing factors, and demonstrate that the critical prostaglandins are produced by PGHS-2. The lack of effect of disrupting PGHS-1 gene expression is consistent with other studies in which stimulated $\mathrm{PGE}_{2}$ responses are associated with PGHS-2 induction (7). However, disruption of PGHS-2 or treatment with NSAIDs only partially blocked PTH- or 1,25-D-stimulated OCL formation in marrow cultures. Therefore, endogenous prostaglandins enhance, but are not required for, PTH- and 1,25-D-stimulated OCL formation. Addition of $\mathrm{PGE}_{2}$ enhanced the effect of PTH but not $1,25-\mathrm{D}$ in $\mathrm{PGHS}-2^{+/+}$cultures, suggesting that endogenous prostaglandins are sufficient to maximize

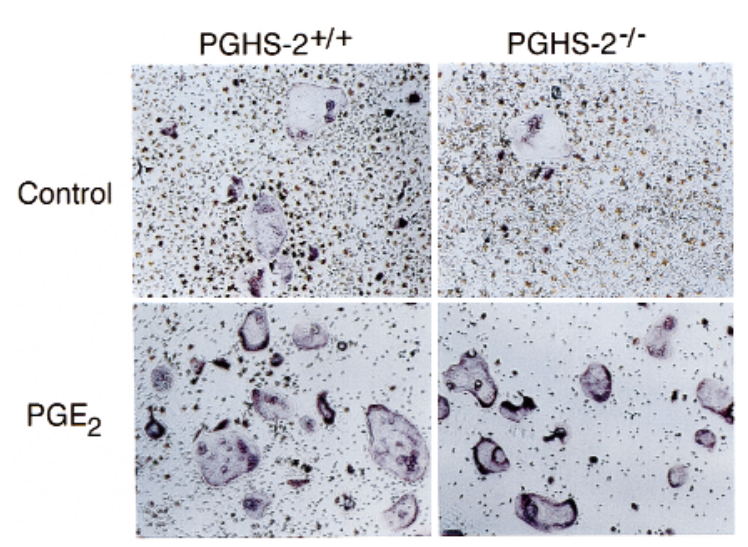

Figure 8

Effect of PGE $E_{2}$ on RANKL- and M-CSF-stimulated spleen cell cultures. RANKL-stimulated $(10 \mathrm{ng} / \mathrm{mL})$ and $M-C S F-$ stimulated $(10 \mathrm{ng} / \mathrm{mL})$ spleen cells from $\mathrm{PGHS}-2^{+/+}$and $\mathrm{PGHS}-2^{-/-}$mice were treated for 6 days with vehicle (Control) or $\mathrm{PGE}_{2}(1 \mu \mathrm{M})$ and then stained for TRAP. 


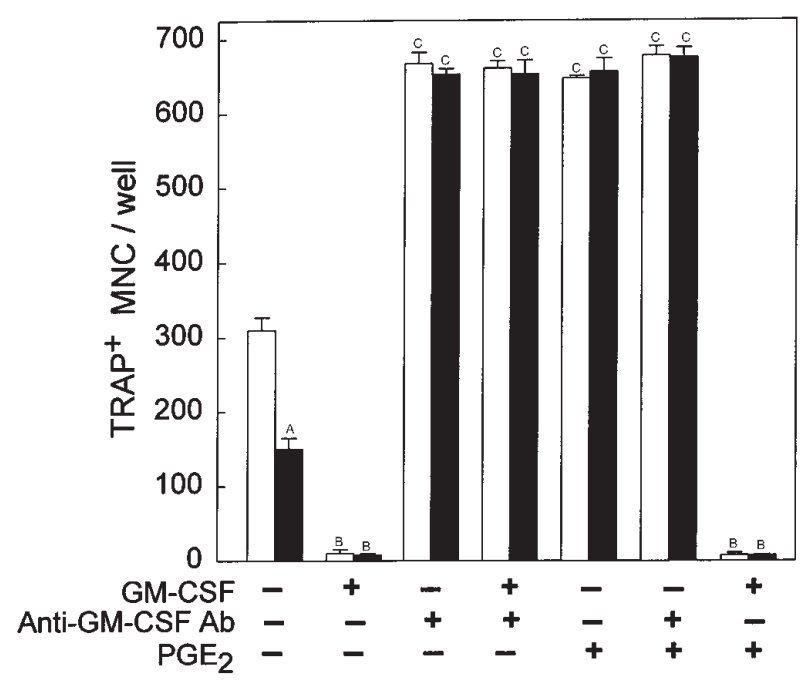

Figure 9

Effects of GM-CSF and a blocking antibody to GM-CSF on TRAP ${ }^{+}$ MNC formation in RANKL- and M-CSF-stimulated spleen cell cultures. Spleen cells from $P G H S-2^{+/+}$(white bars) and $P G H S-2^{-/-}$(black bars) mice were cultured for 6 days with RANKL $(10 \mathrm{ng} / \mathrm{mL})$ and $M$ CSF $(10 \mathrm{ng} / \mathrm{mL})$. Cultures were also treated with vehicle (Control), murine GM-CSF ( $1 \mathrm{ng} / \mathrm{mL})$, murine polyclonal antibody to GM-CSF $(1 \mu \mathrm{g} / \mathrm{mL})$, or $\mathrm{PGE}_{2}(1 \mu \mathrm{M})$. Bars represent mean $\pm \mathrm{SE}$ for quadruplicate cultures. ASignificant effect of-/- genotype; $P<0.01$. ${ }^{B}$ Significant effect of GM-CSF; $P<0.01$. 'Significant effect of anti-GMCSF antibody or $\mathrm{PGE}_{2} ; P<0.01$.

1,25-D- but not PTH-stimulated OCL formation in these cultures.

Despite the dependence of PTH- or 1,25-D-stimulated OCL formation on prostaglandin production, we have not found PTH-stimulated (49) or 1,25-D-stimulated $(50)$ resorption in organ culture to be inhibited by indomethacin. This lack of dependence on prostaglandins is not due to lack of PGHS-2 induction or endogenous prostaglandin production (51). Perhaps stimulated resorption in organ culture reflects differentiation or activation of a pool of available osteoclastic precursors, and the prostaglandin enhancement of stimulated OCL formation in marrow culture reflects increased formation of new osteoclastic precursors.

Formation of bone-resorbing OCLs requires a contact-dependent interaction between osteoclast precursor cells and stromal or osteoblastic cells (12-14). The molecule mediating this interaction was originally cloned as (RANKL) (33), and was found to be identical to TNF-related activation-induced cytokine (TRANCE) (52). Subsequently, TRANCE/RANKL was found to be identical to osteoclast differentiating factor and to be a ligand for osteoprotegerin (a decoy receptor for RANKL) and is therefore also called ODF or OPGL (38). Induction of RANKL is essential for resorption by 1,25-D, PTH, and $\mathrm{PGE}_{2}$ (38-41). Our data suggest that PTH- and 1,25-D-stimulated RANKL mRNA expression in osteoclastic support cells is decreased $50-60 \%$ in the absence of PGHS-2 expression; this reduction could explain the majority of the decrease in stimulat- ed OCL formation in PGHS-2-1- marrow cultures compared with $P G H S-2^{+/+}$marrow cultures.

A recent study showed that $\mathrm{PGE}_{2}$ enhances RANKLstimulated OCL formation in spleen cell cultures, supporting a role for a direct effect of prostaglandins on hematopoietic precursors of osteoclasts (44). Our data support these observations. In addition, we showed a reduction in RANKL- and M-CSF-stimulated OCL formation in spleen cell cultures from $\mathrm{PGHS}-2^{-/-}$mice. This reduction was not reversed by indomethacin, and hence cannot be attributed to a difference in $\mathrm{PGE}_{2}$ production in spleen cell cultures. We suggest that in vivo, prostaglandins modulate the size of the pool of osteoclastic progenitors that are readily available to differentiate in response to stimulators, and that in vitro, in the absence of endogenously produced prostaglandins, these differences are maintained. However, these differences can be overcome by treatment of the spleen cell cultures with exogenous prostaglandins, or the production of prostaglandins by osteoblasts in spleen-osteoblast cocultures.

Our results in spleen cell cultures treated with RANKL and M-CSF suggest that decreased OCL formation in

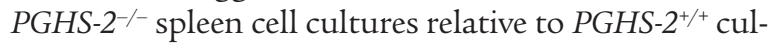
tures is due to increased GM-CSF expression. Several previous studies have found that prostaglandins or cAMP analogues downregulate the expression of GMCSF in marrow stromal cells and lymphocytes (53-55). However, there are conflicting reports on the effects of GM-CSF on osteoclastogenesis in marrow cultures and cocultures. GM-CSF has been found to increase OCL formation in human and primate bone marrow cultures $(56,57)$ and in some rodent cultures $(58-60)$. On the other hand, there are many studies in murine marrow cultures and coculture systems showing that GM-CSF inhibits OCL formation $(45,46,61-63)$, and it has been proposed that GM-CSF inhibits OCL formation by inhibiting expression of integrin $\alpha v \beta 5$ (64). Although GM-CSF knockout mice have been found to have abnormalities in granulopoiesis, resistance to infection, and pulmonary physiology $(65,66)$, we found no reports of abnormal bone histology.

The association of increased GM-CSF expression with decreased OCL formation that was seen in the spleen cell cultures could not be generalized to account for the effect of PGHS-2 deficiency on OCL formation in marrow cultures and cocultures of osteoblasts and spleen cells. Addition of GM-CSF to 1,25-D-stimulated PGHS$2^{+/+}$and PGHS-2 $2^{-/-}$marrow cultures or to PTH-stimulated $\mathrm{PGHS}-2^{+/+}$and $\mathrm{PGHS}-2^{-/-}$osteoblast/spleen cocultures completely inhibited OCL formation, but the blocking antibody to GM-CSF had no effect on OCL formation in the absence of exogenous GM-CSF (data not shown). In addition, we were not able to detect GMCSF mRNA by RT-PCR in marrow cultures from PGHS$2^{+/+}$or $P G H S-2^{-/-}$mice (data not shown).

Because prostaglandins produced by PGHS- 2 are critical for obtaining maximal OCL responses to $1,25-\mathrm{D}$ and $\mathrm{PTH}$, an in vivo role for prostaglandins in bone resorp- 
tion may be most apparent during high bone turnover. Subcutaneous injection of PTH above the calvaria has been shown to increase resorption locally and to cause hypercalcemia in mice $(36,37)$. $P G H S-2^{+/+}$mice subjected to this protocol became hypercalcemic as expected, but $\mathrm{PGHS}-2^{-/-}$mice did not. These studies suggest that the in vivo bone resorption response to high-dose PTH is blunted in PGHS-2-/- mice. Although PGHS-2 deficiency did not result in differences in histologic phenotype or differences in serum calcium levels under conditions of unstimulated turnover, the effect of PGHS-2 deficiency on the resorption response to high-dose PTH suggests that a histologic phenotype may become evident when bone resorption is increased, such as occurs after estrogen withdrawl. Although $P G H S-2^{-/-}$mice may develop renal nephropathy, $P G H S-2^{+/-}$mice remain healthy with age, and have been used to demonstrate effects of reduced PGHS-2 expression in vivo on the incidence of intestinal polyposis (67). In our study, $\mathrm{PGE}_{2}$ production and OCL formation in $\mathrm{PGHS}-2^{+/-}$cultures were each intermediate between that found in $\mathrm{PGHS}-2^{+/+}$ and $\mathrm{PGHS}-2^{-/-}$cultures, suggesting that $\mathrm{PGHS}-2^{+/-}$mice will be useful for studying the effects of PGHS-2 reduction on bone metabolism in vivo.

Histological examination of bone from 5-week-old PGHS-2 $2^{-/}$mice revealed no skeletal abnormalities, which suggests that PGHS-2 is not necessary for normal bone development. However, the effects of PGHS-2 expression on bone cells can be replaced by exogenous prostaglandins, and maternally produced prostaglandins could play a role in fetal skeletal development.

\section{Acknowledgments}

We thank Cindy Alander and Olga Voznesensky for excellent technical help, Eric Mallico for breeding the PGHS knockout animals, B.F. Boyce and Weiguang Zhao for advice on the in vivo PTH injections, and $\mathrm{H}$. Kronenberg and A.M. Flanagan for thoughtful discussions. We are grateful to Dirk Anderson for his gift of osteoclast differentiating factor. This work was supported by National Institutes of Health grants DK48361 (to C. Pilbeam) and AM-18063 (to L. Raisz).

1.Smith, W.L., Garavito, R.M., and DeWitt, D.L. 1996. Prostaglandin endoperoxide $\mathrm{H}$ synthases (cyclooxygenases)-1 and -2. J. Biol. Chem. 271:29569-29575.

2. Kujubu, D.A., Fletcher, B.S., Varnum, B.C., Lim, R.W., and Herschman, H.R. 1991. TIS10, a phorbol ester tumor promoter-inducible mRNA from Swiss 3T3 cells, encodes a novel prostaglandin synthase/cyclooxygenase homologue. J. Biol. Chem. 266:12866-12872.

3. Reddy, S.T., and Herschman, H.R. 1996. Transcellular prostaglandin production following mast cell activation is mediated by proximal secretory phospholipase $\mathrm{A}_{2}$ and distal prostaglandin synthase 1. J. Biol. Chem. 271:186-191.

4. Reddy, S.T., and Herschman, H.R. 1997. Prostaglandin synthase-1 and prostaglandin synthase- 2 are coupled to distinct phospholipases for the generation of prostaglandin $\mathrm{D}_{2}$ in activated mast cells. J. Biol. Chem. 272:3231-3237.

5. Chulada, P.C., and Langenbach, R. 1997. Differential inhibition of murine prostaglandin synthase- 1 and -2 by nonsteroidal anti-inflammatory drugs using exogenous and endogenous sources of arachidonic acid. J. Pharmacol. Exp. Ther. 280:606-613.

6. Swinney, D.C., Mak, A.Y., Barnett, J., and Ramesha, C.S. 1997. Differential allosteric regulation of prostaglandin $\mathrm{H}$ synthase 1 and 2 by arachidonic acid. J. Biol. Chem. 272:12393-12398.
7. Pilbeam, C.C., Harrison, J.R., and Raisz, L.G. 1996. Prostaglandins and bone metabolism. In Principles of bone biology. J.P. Bilezikian, L.G. Raisz, and G.A. Rodan, editors. Academic Press. New York, NY. 715-728.

8. Morham, S.G., et al. 1995. Prostaglandin synthase 2 gene disruption causes severe renal pathology in the mouse. Cell. 83:473-482.

9. Dinchuk, J.E., et al. 1995. Renal abnormalities and an altered inflammatory response in mice lacking cyclooxygenase II. Nature. 378:406-409.

10. Langenbach, R., et al. 1995. Prostaglandin synthase 1 gene disruption in mice reduces arachidonic acid-induced inflammation and indomethacin-induced gastric ulceration. Cell. 83:483-492.

11. Lim, H., et al. 1997. Multiple female reproductive failures in cyclooxygenase 2-deficient mice. Cell. 91:197-208.

12. Martin, T., and Udagawa, N. 1998. Hormonal regulation of osteoclast function. Trends Endocrinol. Metab. 9:6-12.

13. Reddy, S.V., and Roodman, G.D. 1998. Control of osteoclast differentiation. Crit. Rev. Eukaryot. Gene Expr. 8:1-17.

14. Suda, T., et al. 1999. Modulation of osteoclast differentiation and function by the new members of the tumor necrosis factor receptor and ligand families. Endocr. Rev. 20:345-357.

15. Klein, D.C., and Raisz, L.G. 1970. Prostaglandins: stimulation of bone resorption in tissue culture. Endocrinology. 86:1436-1440.

16. Tashiian, A.H.J., Hohmann, E.L., Antoniades, H.N., and Levine, L. 1982. Platelet-derived growth factor stimulates bone resorption via a prostaglandin-mediated mechanism. Endocrinology. 111:118-124.

17. Sato, K., et al. 1986. Stimulation of prostaglandin $\mathrm{E}_{2}$ and bone resorption by recombinant human interleukin $1 \alpha$ in fetal long bone. Biochem. Biophys. Res. Comm. 138:618-624.

18. Akatsu, T., et al. 1991. Role of prostaglandins in interleukin-1-induced bone resorption in mice in vitro. J. Bone Miner. Res. 6:183-189.

19. Stern, P.H., et al. 1985. Human transforming growth factor-alpha stimulates bone resorption in vitro. J. Clin. Invest. 76:2016-2019.

20. Tashjian, A.H., et al. 1987. Tumor necrosis factor- $\alpha$ (cachectin) stimulates bone resorption in mouse calvaria via a prostaglandin-mediated mechanism . Endocrinology. 120:2029-2036.

21. Tai, H., et al. 1997. Transcriptional induction of cyclooxygenase- 2 in osteoblasts is involved in interleukin-6-induced osteoclast formation. Endocrinology. 138:2372-2379.

22. Sato, T., et al. 1996. Involvement of prostaglandin endoperoxide H synthase-2 in osteoclast-like cell formation induced by interleukin-1ß.J. Bone Miner. Res. 11:392-400.

23. Lader, C.S., and Flanagan, A.M. 1998. Prostaglandin $\mathrm{E}_{2}$, interleukin $1 \alpha$, and tumor necrosis factor- $\alpha$ increase human osteoclast formation and bone resorption in vitro. Endocrinology. 139:3157-3164.

24. Inoue, H., Tanaka, N., and Uchiyama, C. 1995. Parathyroid hormone increases the number of tartrate-resistant acid phosphatase-positive cells through prostaglandin $\mathrm{E}_{2}$ synthesis in adherent cell culture of neonatal rat bones. Endocrinology. 136:3648-3656.

25. Sato, T., Morita, I., and Murota, S. 1997. Prostaglandin $\mathrm{E}_{2}$ mediates parathyroid hormone induced osteoclast formation by cyclic AMP independent mechanism. Adv. Exp. Med. Biol. 407:383-386.

26. Collins, D.A., and Chambers, T.J. 1992. Prostaglandin $\mathrm{E}_{2}$ promotes osteoclast formation in murine hematopoietic cultures through an action on hematopoietic cells. J. Bone Miner. Res. 7:555-561.

27. Girasole, G., Passeri, G., Jilka, R.L., and Manolagas, S.C. 1994. Interleukin-11: a new cytokine critical for osteoclast development. J. Clin. Invest. 93:1516-1524.

28. Morinaga, Y., Fujita, N., Ohishi, K., Zhang, Y., and Tsuruo, T. 1998. Suppression of interleukin-11-mediated bone resorption by cyclooxygenases inhibitors. J. Cell. Physiol. 175:247-254.

29. Amano, S., et al. 1994. Phorbol myristate acetate stimulates osteoclast formation in $1 \alpha, 25$-dihydroxyvitamin $\mathrm{D}_{3}$-primed mouse embryonic calvarial cells by a prostaglandin-dependent mechanism. J. Bone Miner. Res. 9:465-472.

30. Hurley, M.M., Lee, S.K., Raisz, L.G., Bernecker, P., and Lorenzo, J. 1998. Basic fibroblast growth factor induces osteoclast formation in murine bone marrow cultures. Bone. 22:309-316.

31. Kotake, S., et al. 1999. IL-17 in synovial fluids from patients with rheumatoid arthritis is a potent stimulator of osteoclastogenesis. J. Clin. Invest. 103:1345-1352.

32. Chomczynski, P., and Sacchi, N. 1987. Single-step method of RNA isolation by acid guanidinium thiocyanate-phenol-chloroform extraction. Anal. Biochem. 162:156-159.

33. Anderson, D.M., et al. 1997. A homologue of the TNF receptor and its ligand enhance T-cell growth and dendritic-cell function. Nature. 390: $175-179$.

34. Raisz, L.G., and Simmons, H.A. 1985. Effects of parathyroid hormone and cortisol on prostaglandin production by neonatal rat calvaria in vitro. Endocr. Res. 11:59-74.

35. Pilbeam, C.C., Fall, P.M., Alander, C.B., and Raisz, L.G. 1997. Differential effects of nonsteroidal anti-inflammatory drugs on constitutive and inducible prostaglandin $\mathrm{G} / \mathrm{H}$ synthase in cultured bone cells. J. Bone Miner. Res. 12:1198-1203. 
36. Yates, A.J., et al. 1988. Effects of a synthetic peptide of a parathyroid hormone-related protein on calcium homeostasis, renal tubular calcium reabsorption, and bone metabolism in vivo and in vitro in rodents. J. Clin. Invest. 81:932-938.

37. Zhao, W., Byrne, M.H, Boyce, B.F., and Krane, S.M. 1999. Bone resorption induced by parathyroid hormone is strikingly diminished in collagenase-resistant mutant mice. J. Clin. Invest. 103:517-524.

38. Yasuda, H., et al. 1998. Osteoclast differentiation factor is a ligand for osteoprotegerin/osteoclastogenesis-inhibitory factor and is identical to TRANCE/RANKL. Proc. Natl. Acad. Sci. USA. 95:3597-3602.

39. Horwood, N.J., Elliott, J., Martin, T.J., and Gillespie, M.T. 1998. Osteotropic agents regulate the expression of osteoclast differentiation factor and osteoprotegerin in osteoblastic stromal cells. Endocrinology. 139:4743-4746

40. Tsukii, K., et al. 1998. Osteoclast differentiation factor mediates an essential signal for bone resorption induced by $1 \alpha, 25$-dihydroxyvitamin $\mathrm{D}_{3}$, prostaglandin $\mathrm{E}_{2}$, or parathyroid hormone in the microenvironment of bone. Biochem. Biophys. Res. Commun. 246:337-341.

41. Lee, S.-K., and Lorenzo, J.A. 1999. Parathyroid hormone stimulates TRANCE and inhibits osteoprotegerin mRNA expression in murine bone marrow cultures: correlation with osteoclast-like cell formation. Endocrinology. 140:3552-3561.

42. Lacey, D.L., et al. 1998. Osteoprotegerin ligand is a cytokine that regulates osteoclast differentiation and activation. Cell. 93:165-176.

43. Quinn, J.M., Elliott, J., Gillespie, M.T., and Martin, T.J. 1998. A combination of osteoclast differentiation factor and macrophage-colony stimulating factor is sufficient for both human and mouse osteoclast formation in vitro. Endocrinology. 139:4424-4427.

44. Wani, M.R., Fuller, K., Kim, N.S., Choi, Y., and Chambers, T. 1999. Prostaglandin $\mathrm{E}_{2}$ cooperates with TRANCE in osteoclast induction from hemopoietic precursors: synergistic activation of differentiation, cell spreading, and fusion. Endocrinology. 140:1927-1935.

45. Udagawa, N., et al. 1997. Interleukin-18 (interferon-gamma-inducing factor) is produced by osteoblasts and acts via granulocyte/macrophage colony-stimulating factor and not via interferon-gamma to inhibit osteoclast formation. J. Exp. Med. 185:1005-1012.

46. Horwood, N.J., et al. 1998. Interleukin 18 inhibits osteoclast formation via $T$ cell production of granulocyte macrophage colony-stimulating factor. J. Clin. Invest. 101:595-603.

47. Collins, D.A., and Chambers, T.J. 1991. Effect of prostaglandins E1, E2, and $\mathrm{F} 2$ alpha on osteoclast formation in mouse bone marrow cultures. J. Bone Miner. Res. 6:157-164.

48. Kaji, H., et al. 1996. Prostaglandin $\mathrm{E}_{2}$ stimulates osteoclast-like cell formation and bone-resorbing activity via osteoblasts: role of cAMPdependent protein kinase. J. Bone Miner. Res. 11:62-71.

49. Kawaguchi, H., et al. 1996. Interleukin-4 inhibits prostaglandin G/H synthase-2 and cytosolic phospholipase A2 induction in neonatal mouse parietal bone cultures. J. Bone Miner. Res. 11:358-366.

50. Klein-Nulend, J., Pilbeam, C.C., and Raisz, L.G. 1991. Effect of 1,25dihydroxyvitamin $\mathrm{D}_{3}$ on prostaglandin $\mathrm{E}_{2}$ production in cultured mouse parietal bones. J. Bone Miner. Res. 6:1339-1344.

51. Kawaguchi, H., et al. 1994. Regulation of the two prostaglandin G/H synthases by parathyroid hormone, interleukin-1, cortisol and prostaglandin $\mathrm{E}_{2}$ in cultured neonatal mouse calvariae. Endocrinology. 135:1157-1164

52. Wong, B.R., et al. 1997. TRANCE is a novel ligand of the tumor necrosis factor receptor family that activates c-Jun $\mathrm{N}$-terminal kinase in $\mathrm{T}$ cells. J. Biol. Chem. 272:25190-25194.
53. Borger, P., Kauffman, H.F., Vijgen, J.L., Postma, D.S., and Vellenga, E. 1996. Activation of the cAMP-dependent signaling pathway downregulates the expression of interleukin-3 and granulocyte-macrophage colony-stimulating factor in activated human T lymphocytes. Exp. Hematol. 24:108-115.

54. Emond, V., Fortier, M.A., Murphy, B.D., and Lambert, R.D. 1998. Prostaglandin $\mathrm{E}_{2}$ regulates both interleukin-2 and granulocytemacrophage colony-stimulating factor gene expression in bovine lymphocytes. Biol. Reprod. 58:143-151.

55. Bug, G., Aman, J., Huber, C., Peschel, C., and Derigs, H.G. 1998. cAMP analogues downregulate the expression of granulocyte macrophage colony-stimulating factor (GM-CSF) in human bone marrow stromal cells in vitro. Mediators Inflamm. 7:195-199.

56. Povolny, B.T., and Lee, M.Y. 1993. The role of recombinant human MCSF, IL-3, GM-CSF and calcitriol in clonal development of osteoclast precursors in primate bone marrow. Exp. Hematol. 21:532-537.

57. Menaa, C., et al. 1999. Annexin II increases osteoclast formation by stimulating the proliferation of osteoclast precursors in human marrow cultures. J. Clin. Invest. 103:1605-1613.

58. Horowitz, M.C., Coleman, D.L., Flood, P.M., Kupper, T.S., and Jilka, R.L. 1989. Parathyroid hormone and lipopolysaccharide induce murine osteoblast-like cells to secrete a cytokine indistinguishable from granulocyte-macrophage colony-stimulating factor. J. Clin. Invest. 83:149-157.

59. Liggett, W.J., et al. 1993. Effects of macrophage colony stimulating factor and granulocyte-macrophage colony stimulating factor on osteoclastic differentiation of hematopoietic progenitor cells. Stem Cells. 11:398-411.

60. Hattersley, G., and Chambers, T.J. 1990. Effects of interleukin 3 and of granulocyte-macrophage and macrophage colony stimulating factors on osteoclast differentiation from mouse hemopoietic tissue. J. Cell. Physiol. 142:201-209.

61. Takahashi, N., et al. 1991. Role of colony-stimulating factors in osteoclast development. J. Bone Miner. Res. 6:977-985.

62. Shuto, T., Kukita, T., Hirata, M., Jimi, E., and Koga, T. 1994. Dexamethasone stimulates osteoclast-like cell formation by inhibiting granulocyte-macrophage colony-stimulating factor production in mouse bone marrow cultures. Endocrinology. 134:1121-1126.

63. Shuto, T., Jimi, E., Kukita, T., Hirata, M., and Koga, T. 1994. Granulocyte-macrophage colony stimulating factor suppresses lipopolysaccharide-induced osteoclast-like cell formation in mouse bone marrow cultures. Endocrinology. 134:831-837.

64. Feng, X., Teitelbaum, S.L., Quiroz, M.E., Towler, D.A., and Ross, F.P. 1999. Cloning of the murine beta5 integrin subunit promoter. Identification of a novel sequence mediating granulocyte-macrophage colonystimulating factor-dependent repression of beta5 integrin gene transcription. J. Biol. Chem. 274:1366-1374.

65. Stanley, E., et al. 1994. Granulocyte/macrophage colony-stimulating factor-deficient mice show no major perturbation of hematopoiesis but develop a characteristic pulmonary pathology. Proc. Natl. Acad. Sci. USA. 91:5592-5596.

66. Seymour, J.F., et al. 1997. Mice lacking both granulocyte colony-stimulating factor (CSF) and granulocyte-macrophage CSF have impaired reproductive capacity, perturbed neonatal granulopoiesis, lung disease, amyloidosis, and reduced long-term survival. Blood. 90:3037-3049.

67. Oshima, M., et al. 1996. Suppression of intestinal polyposis in Apc delta716 knockout mice by inhibition of cyclooxygenase 2 (COX-2). Cell. 87:803-809. 